\title{
Modernity and Islamic religious consciousness
}

Raja Bahlul

According to Jürgen Habermas, religious consciousness (in the West) has been undergoing a process of modernization since the Reformation and Enlightenment. This modernization has been taking place in response to challenges which include encounters with a plurality of religions and other worldviews, the emergence of modern science, and the spread of positive law and secular morality. These challenges have motivated efforts to re-conceive the relation between secular and religious knowledge, as well as efforts to relate religion to other worldviews, and to uncover human and universal aspects implicit in religion (Habermas 2006: 13-14).

Given that Arab/Muslim societies have been undergoing modernization for more than a century and half, partly as a result of their colonial experience and subsequent integration in a Western-dominated world economy, and partly as a result of internally driven efforts at reform, the question naturally arises as to whether religious consciousness in these societies has also been undergoing modernization. ${ }^{1}$

This question has been answered many times, even if the answer has not always been the same. Thus fundamentalist movements, with their radical old-fashioned ideas about society have been called 'anti-modern' (Ayubi 1991: 231), but their forms of mobilization and motivations have sometimes been viewed as 'modern' (Habermas 1996: 271; Azmeh 1993: 85). Modernity has also been attributed to 'modern' Islamic thinkers such as Muhammad Abduh and Jamal al-Din al-Afghani, Qasim Amin and Ali 'Abd al-Raziq at the beginning of the 20th century. It continues to be attributed to many more thinkers and Islamic modes of thought at present.

Discussions of religion and modernity in the West and in Arab/Muslim countries reveal many differences in the nature, purpose and scope of the discussion. This is only to be expected, for in the West such discussions are framed in the context of a relatively long tradition of secularism, whereas in Islamic countries the issue of secularism is far from resolved. Then there are also differences in religion: Christianity differs from Islam in its history, doctrine and, consequently, the inflections that it was able to take - the role that it eventually came to accept in the political life of modern Western societies. ${ }^{2}$ Finally, there is the fact of modernity itself, original in the West but at best a recent export to, or a violent imposition on much of the Muslim world. ${ }^{3}$ 
Raja Bahlul

Yet beneath the layer of admittedly important differences, the questions, options, demands, expectations and tensions that modern (secular) and religious citizens and societies face remain basically the same. In what follows I want to explore some of the issues, focusing on what may be called 'political modernity': that is, modernity in its political aspect.

Modernity, of course, is a multi-faceted historical process which manifests itself not only in politics, but in the economy, science, philosophy, education, social organization, law and culture, and many other areas as well. There is a reason for my choice of focus, however: I accept Rawls' argument that the values of the political domain have supremacy over other values. Political values such as right(s), justice, equality, freedom and others have a large-scale effect in that they govern the basic framework of social life (Rawls 1993: 139). Not only that, but political power (as 'the coercive power of free and equal citizens as a corporate body' (Rawls 1993: 139)) is more far-reaching and final than any other power that can be exercised by society. There is no escape from the power of the state, which, in Weber's famous statement, is 'that human community which (successfully) lays claim to the monopoly of legitimate physical force' (Lassman and Speirs 1994: 310). Because the political domain stands to have a determining effect on other domains, and because of the far-reaching consequences of political power, it can be claimed that the political dimension of modernity deserves to frame the discussion of religion in modern times.

A suitable starting point which leads directly to the issues we want to discuss here is provided by a remarkable conceptual affinity, a meeting of minds, if you will, between two well-known political philosophies embedded in Western and in recent Islamic tradition: political liberalism and liberal Islamism. Both may be viewed as instances of modern political thinking, as well as reflection on religion in the context of modernity.

Political liberalism is mainly associated with the name of John Rawls. It is a fairly welldefined doctrine, considering that it has been championed by a major political thinker who has engaged in extended dialogues with many critics and supporters. The same cannot be said for liberal Islamism, which subsumes many Islamic thinkers. Nevertheless, the idea of liberal Islamism has some currency, as evidenced by the titles of two important publications, namely those of Leonard Binder (1988) and Charles Kurzman (1998). The term has (or can be given) definite content, as we will do in due course.

\section{Political liberalism and religion}

Political liberalism is the answer to an important question that makes sense only in the context of modernity: ' . . h how is it possible for there to exist over time a just and stable society of free and equal citizens, who remain profoundly divided by reasonable religious philosophical, and moral doctrines?' (Rawls 1993: 4). This is a particularly 'modern' question in that it views religion (along with moral and philosophical theories) as a set of beliefs, or 'doctrines' as Rawls says. Religion is not regarded as a 'science', nor is it viewed as a way in which an entire life-world may be structured. It is merely 'religious belief' or 'opinion'. According to Talal Asad, this way of viewing religion first established itself in the 17th and 18th centuries, when 'religion was forcibly defined as belief to be viewed as a personal matter of private life (Asad 1993: 205).

Political liberalism is a set of ideas and principles based on the rights and liberties familiar in contemporary constitutional democratic regimes (Rawls 1993: 223). ${ }^{4}$ It should be, according to Rawls, an object of consensus among the citizens who make up society, with each 'reasonable' religious, philosophical or moral doctrine endorsing this political conception from its point of view (Rawls 1993:134). Thus political liberalism is to be seen as a non-sectarian position. In fact, the main point of this view lies in its supposed neutrality: 
For rather than confronting religious and non-liberal doctrines with comprehensive liberal philosophical doctrine, the thought is to formulate a liberal political conception that those non-liberal doctrines might be able to endorse.

(Rawls 1993: xlvii)

Given this claim of neutrality, it is interesting to see the manner in which religious citizens are allowed to express themselves in public discussions. According to Rawls, when one engages in public discussions over essential constitutional matters and basic justice in society, one is not permitted to invoke reasons and arguments that have their foundations in one's religious doctrine. There is room for the exchange of reasons only within 'a conception that expresses political values that others as free and equal also might reasonably be expected [ ... ] to endorse' (Rawls 1993: 1). This, of course, excludes religious reasons which non-religious citizens cannot be expected to endorse.

Other authors, writing in a more or less liberal vein, advocate a harder or softer line than we find in Rawls. Audi, for example, requires that a public (non-religious) reason must have such a motivational power that 'one would act on it even if, other things remaining equal, one's other reasons were eliminated' (Audi 1997: 29). Habermas, on the other hand, believes that the secular state 'has an interest in not reducing the polyphonic complexity of public voices, so as not to cut itself off from key resources for the creation of identity and meaning' (Habermas 1996: 10). Secular citizens have a duty to listen patiently and help in the translation of religious language into a language that is accessible to all. Still, Habermas does not allow non-secular reasons to operate beyond a certain point. Says Habermas, 'Every citizen must know and accept that only secular reasons count beyond the institutional threshold that divides the informal public sphere from parliaments, courts, ministries and administrations' (Habermas 1996: 9).

It is evident that liberal writers assume that religious citizens must be prepared to translate their religiously grounded positions into a secular, public language with which secular citizens can critically engage, but how is this to be accomplished? According to Audi, religious citizens should dwell on the basic ethical-humanistic message of religion, instead of the metaphysical foundations of religious morality. This is not a hard or an unfair demand, because of the 'overlap between religiously and secularly grounded obligations in the Hebraic-Christian tradition' (and the Islamic tradition, too, one should add) (Audi 1997: 13). The idea here (which has been championed by Audi and others) is that the all-knowing and all-good God of the Abrahamic faiths would structure our minds and our world so that we are able to use our reason to arrive at the ideas and principles needed to organize our social-political life in a way that accords with divine will.

\section{Liberal Islamism}

Thinkers to be viewed as 'liberal Islamists' here all share attributes that have been used to describe a larger class of Islamic 'modernists' or 'reformists': attributes such as perceiving Islam in terms of 'openness' and 'dynamism' (Stowasser 1993: 3); interpreting Islam creatively (Azmeh 1993: 33); preference of ijtihad (independent interpretation) over taqlid (tradition-following) (Kurzman 1998: 8); and 'reinterpret[ing] Islamic concepts so as to make them equivalent to the guiding principles of European Thought' (Hourani 1962: 344).

However, such descriptions are with some justice applicable to many thinkers who differ significantly from one another. Not all Islamic modernists are equally modern, nor are they are all very modern to begin with; in fact, some of them advocate ideas that are fairly close to being fundamentalist. For these reasons it matters much to say precisely who the liberal Islamists are and what distinguishes them from others. 
Raja Bahlul

A good way to get to know what liberal Islamists stand for is to dwell on the views of other, somewhat moderate thinkers who cannot without hesitation be called liberal. Take Turabi, Ghannouchi and Khatami, for example. These writers are well known for their advocacy of peaceful Islamic engagement in politics. They can be viewed as 'democrats' in some sense, because to them popular consent is necessary for political legitimacy. According to Khatami:

... popular will [is] a main condition for the establishment and durability of the state [... ] I can imagine a state being established contrary to popular will and desire, but I find it difficult to imagine its being a stable and durable state [ ... ] It is not possible for an Islamic state to come to being, nor can an Islamic state last regardless of the people and what they choose [ ... ] Besides, nobody can choose a non-democratic path without having recourse to the use of force. There is simply no third way; those who reject the path of democracy are calling for dictatorship and coercion.

(Khatami 1998: 86, 99)

Ghannouchi expresses his belief in democracy by saying that:

$\ldots$ it is possible for the mechanisms of democracy [ . . ] to operate in different cultural milieus [ ... Democracy] resolves itself into popular sovereignty, equality between citizens, governing bodies which emerge from popular will through free elections, [ ... ] recognition of the majority's right to rule [ ... There is nothing in these procedures which is necessarily in conflict with Islamic values.

(Ghannouchi 1993: 88)

Finally, Turabi is not far behind with his belief that:

Islamic jurisprudence has known the essence of democracy, or government by the people, since the day Muslims believed in the One God, [... knowing that they are equal in worshipping Him, and that they are His vice-regents on earth.

(Turabi 1987: 42)

Nevertheless, these thinkers are able to offer justifications for privileging Islam in the matter of law-making and methods of governing. Turabi explicitly says that 'popular sovereignty does not mean that people have absolute power. Power is limited by commitment to Shari'a' (Turabi 1987: 66). Elsewhere he reassuringly says that the power of government is limited by Shari'a, only to add that nobody is exempt from the power of Shari'a: 'The legislature, the Congress, or Parliament or whatever, is not sovereign at all. The Shar'ia governs so much' (Lowrie 1993: 25). Ghannouchi is no less explicit. According to him, 'the legitimate sphere of people's sovereignty cannot go beyond God's law as stated in the Qur'an and the Sunna' (Ghannouchi 1993: 109). Nor does democracy fare much better with Khatami. Pressed (in an interview) to say whether 'religiously different' persons can reach high decision-making positions in an Islamic state, Khatami wavers at length. In the end he says vaguely that in the Islamic state, 'religion defines the conditions and background circumstances', that 'if people modify the constitution by allowing the religiously different to reach supreme decision-making position then this is a different matter' (Khatami 1998: 105ff). ${ }^{5}$

There are also difficulties with regard to positions taken by 'moderate' thinkers on matters of gender equality and equal citizenship. Many of them are unable to acknowledge women's right to assume positions of leadership in society or the idea of political equality regardless of faith. 
There are also limits on permissible pluralism: it has to be pluralism within a broadly Islamic framework of ideas, where opinions can diverge between an Islamically defined 'extreme conservatism' and an Islamically defined 'extreme modernism'. The gamut is hardly convincing, to judge from the examples given by Qaradawi: an 'extreme conservative' might advocate the view that non-Muslims should pay jizyah (poll tax) even in wartime, whereas an 'extreme modernist' may advocate the view that leaders should be elected by popular vote (Qaradawi 1993: 637-38; other examples can be found in Ghannouchi 1993: 295; Turabi 1987: 67-68).

Because Turabi, Ghannouchi, Khatami and many others like them seek to Islamize democracy, because they advocate peaceful engagement in politics, and because they gradually learned to distance themselves from militant Islamic movements and ideologies - for all these reasons it may be unfair to classify them with the fundamentalists. Still, many analysts continue to have doubts about their intentions and final aim, believing that their advocacy of democracy is purely instrumental (opportunistic), and that no sharp line separates them from the fundamentalists (Azmeh 1994: 127; Brown et al. 2006: 4; Denouex 2002: 72-78).

However, if thinkers such as Khatami, Turabi and Ghannouchi are not to be viewed as 'liberal', who can be? What does one have to believe in to be counted a liberal Islamist? According to Kurzman, a liberal Islamist is 'liberal in some sense of the word (in particular, those who express opposition to Islamic revivalism)', and 'Islamic in some sense of the word (those who believe that Islam has an important role in the contemporary world, as opposed to secularists)' (Kurzman 1998: 18). While it is difficult to disagree with the second part of the characterization, the first part is hardly satisfactory. It is a purely negative definition which many non-liberal Islamists easily satisfy; after all, opposition to Islamic revivalism, especially its militant varieties, is widespread.

In situations of unresolved terminological ambiguity, often the best way to make progress is to introduce an element of stipulation, which simply means saying that by such and such a term one chooses to understand such and such. Stipulation is not the same as arbitrariness or sheer willfulness of usage. One stipulates to delineate boundaries beyond which dispute is, for certain purposes, fruitless or time-wasting.

Taking as our starting point the fact that 'liberal Islamists' tend to be more advanced in their advocacy of democracy, pluralism and the need to draw boundaries between religion and politics than any of the writers mentioned above, we stipulate that a liberal Islamist is someone who accepts the following three ideas. Thus we view liberal Islamism as an 'ideal type' which can be exemplified in varying degrees of clarity and completeness.

First, the idea of differentiation. Stepan calls this 'the Twin Tolerations', which means that 'religious institutions should not have constitutionally privileged prerogatives that allow them to mandate public policy to democratically elected governments. At the same time, individuals and religious communities [... ] must have complete freedom to worship privately' (Stepan 2005: 5).

Second, the idea of constitutionalism. The writer must accept a plausible version of human rights, together with recognition that human rights principles prevail over any Shari'a laws in cases of conflict. ${ }^{6}$

Last, the idea of democracy. This is the idea of equal and inclusive citizenship, so that gender nor religion nor ethnicity is politically relevant.

To these we can add two more ideas which may be viewed as direct or indirect consequences of differentiation, constitutionalism and democracy. 1 On the individual level, Islam is to be understood in terms of personal religious observance and individual piety and spiritual life. 2 On the social level, Islam is to be understood in terms of universal ethical principles that can give direction to social and government policies, but only through peaceful participation in politics. 
Raja Bahlul

The ideas that we take here to be definitive of liberal Islamism are closely related to each other. Democracy, inasmuch as it can be viewed as the institutionalization of the ideas of equality and liberty, is already implicit in the idea of human rights. The idea of human rights, it may be argued, requires a situation of differentiation between the political and the religious. For there may be no way for securing equality and liberty and other human rights values under conditions where religious faith has political consequences.

Still, despite conceptual connections, it need not be the case that all ideas that make up liberal Islamism are equally developed in all the writers who may be claimed for liberal Islam. In view of this, the best way to get a measure of liberal Islamism in the concrete is to dwell on basic liberal ideas advocated by different writers. Only in this way can one appreciate the unqualified acceptance of liberal ideas, something which is missing in many modern, but non-liberal writers of greater fame.

The first, and probably best-known, writer who deserves to be mentioned, is Ali 'Abd al-Raziq. To him Islam is a religion - ideas and values, but not a political program, nor a blueprint for building a state.

Islam is a religious call to God and is a school of thought, from many such schools which seek to reform a certain type of people, guiding them to what will render them closer to God $[\ldots]$ and opening up the path to everlasting happiness ...

('Abd al-Raziq 1998: 34)

To prove this, 'Abd al-Raziq uses different methods, ranging from novel interpretations (or reinterpretations) of Qur'anic texts, to drawing implications from past historical practices, to using purely rational considerations. Regardless of their strength and validity, 'Abd al-Raziq's arguments serve to draw boundaries between religion and politics in a clear and unequivocal way. His proposal to view Islam as one school of thought among others is bound to be congenial for a political liberal like John Rawls, who is anxious to make peace among the different competing 'reasonable doctrines' which (he hopes) will accept political liberalism 'each from its point of view'.

Another writer, Abdullahi an-Naim, in effect calls for the abrogation of the historical Shari'a and its replacement by one that is based on the ethical-humanistic message contained in the earlier Qur'anic revelation (prior to the establishment of the first Islamic polity in Medina in $622 \mathrm{AD})$. This earlier message of Islam, argues an-Naim, is fully compatible with the modern notions of human rights and inclusive, non-discriminative citizenship (an-Naim 1990: 179).

Fazlur Rahman offers a criterion of Islamicity which requires a holistic interpretation of the Qur'an and the Prophetic Sunna. To him, 'a doctrine or an institution is genuinely Islamic to the extent that it flows from the total teaching of the Qur'an and the Sunna ...' (Rahman 1982: 22, emphasis added). Given that the totality of Islamic teachings aims at the establishment of a 'community of justice and goodness' (Rahman 1982: 13), granting authority only to holistic interpretations has the effect of a license to re-construe all legal enactments that are inconsistent with these aims, including probably all currently controversial Shari'a laws. Rahman clearly distinguishes between legal enactments and moral principles. He regards the latter as having a more authoritative status, because, in his view, the Qur'an is not to be conceived of as a law book, but as a religious source of law (Rahman 1980: 47).

Khalid Abou el-Fadl gives traditionally interpreted Shari'a its due by saying that its endorsement of the ideas of the rule of law and limited government signifies its acceptance of 'core elements of modern democratic practice', but this is not enough. Abou el-Fadl insists on unqualified acceptance of popular sovereignty: 
Democracy's moral power lies in the idea that the citizens of a nation are sovereign, $[\ldots]$ and they express their sovereign will by electing representatives. In a democracy, the people are the source of the law, and the law in turn ensures the fundamental rights that protect the well-being and interests of the individual members of the sovereignty.

(Abou el-Fadl 2004: 4)

To Abou el-Fadl Shari'a should not be viewed as particular, historically conditioned legal enactments; rather, it should be understood in terms of divine intentions, and principles of divine mercy and justice. '[ ... i i]t ought to stand in an Islamic polity as a symbolic construct for the divine perfection that is unreachable by human effort' (Abou el-Fadl 2004: 22, 33).

The distinction between divine and non-divine aspects of religion is also made by 'AbdulKarim Soroush. 'Religion is divine', writes Soroush, 'but its interpretation is thoroughly human and this-worldly' (Soroush 1998: 246). He reaches this conclusion via a Kantian understanding of knowledge, and a post-positivistic philosophy of science:

... the [religious] text does not stand alone, it does not carry its own meaning on its shoulders, its interpretation is in flux, and presuppositions are actively at work here and elsewhere in the field of understanding[ ... T These assumptions can be of very different nature, ranging from philosophical, historical, and theological to the more specific assumptions such as linguistic and sociological ones.

(Soroush 1998: 245)

Consequently, Soroush (like other liberal Islamists) is led to distinguish between moral principles (and divine intentions) and earthly interpretations that go 'through the reason of the age' (Soroush 1998: 251). This distinction, in liberal Islamist hands, is used to bring Islam into conformity with contemporary liberal ideas about politics and social life.

An indication of how far liberal Islamism is willing to go in the direction of privatizing religion can be obtained from this seemingly naïve and simple admission to be found in Mohammad Talbi. According to this author:

$\ldots$ it is possible for a Muslim to live content in his Islam and to live a full Islamic life in London, for example, where the government is in the hands of Mrs. Thatcher. This government would never prevent the Muslim living an excellent and satisfying Islamic life, while the Muslim in another system which claimed to be an Islamic order, might be suppressed and subjugated.

(Talbi 1992: 101)

As a corrective to this, however, it should be emphasized that liberal Islamists do not generally advocate a withdrawal into private life, a closing of the door on public life and political involvement. According to Fazlur Rahman the ultimate goal of the Islamic faith is the establishment of an 'ethically-based socio-economic order' (Rahman 1982: 13), something which can hardly be done without involvement in politics. What makes such Islamic advocacy liberal is the fact that the advocates are willing to accept pluralism and democratic methods of work.

\section{Estimate of liberal Islamism}

Liberal Islamism fits Rawls' description of 'the reasonable doctrines [which] endorse the political conception, each from its point of view' (Rawls 1993: 134). This fact invites many questions. 
Raja Bahlul

Does liberal Islamism represent religious consciousness in any meaningful sense of the term? Does it represent a modern understanding of Islam, or an Islamic version of modernity? How satisfactory is it? Finally, a question about the questions themselves: can they be answered objectively?

Many writers would say that the modernization of religious consciousness that is represented by liberal Islamism is not genuine intellectual accomplishment, but rather a work of 'epistemological legerdemain', in Azmeh's expressive terms (Azmeh 1993: 33). The reasons by no means constitute a conclusive argument, but it is instructive to look at some of them.

Some critics charge that liberal Islamists willfully ignore texts that contradict their understanding of Islam. Such is the view of Fahmi Jadaane who claims that 'Abd al-Raziq's attempt to present Islam as a spiritual, non-political faith ignores a multitude of Qur'anic texts and Prophetic practices that are all patently political in nature, such as the collection of taxes, the conduct of relations with other nations, the waging of war and the conclusion of peace treaties (Jadaane 1981: 342).

However, while this may occasionally be true, liberal Islamists cannot be accused as a group of being unaware of religious texts that seem to contradict their understanding of Islam. This is precisely why they engage in work of interpretation, their aim being to show that the problematic texts need mean what they seem to mean. This is why texts that seem to accept slavery, discrimination against women or inhumane punishments, in addition to 'political texts', have become standard hermeneutical exercises for liberal and modern Islamists.

This, however, is not the end of the story, for liberal interpretations of Islam - in fact, liberal interpretations of religion in general - have been subjected to many criticisms. Critics claim that modernist interpretations of religion involve taking many liberties with the 'original' meaning of the texts, the way texts were understood and practiced by the founders. Such is the view of Earnest Gellner whose estimate of modernist interpretations of religion in general can be applied to liberal Islamism in particular. In such 'softened modernist re-interpretations' of religion, says Gellner, 'the doctrines and the moral demands of the faith are [ ... ] turned into something which, properly interpreted, is in astonishingly little conflict with the secular wisdom of the age, or indeed with anything. This way lies peace - and doctrinal vacuity' (Gellner 1992: 4). Taking Christianity as his example, Gellner has the modernist interpreter saying - quite implausibly, of course - that 'the founder of the dominant Western faith had to use simple language because if he talked modern philosophy they would not have understood him. But he really meant the latest philosophic fashion' (Gellner 1993: 40).

In addition to taking great liberties with the meanings and intention of God and the founders, liberal interpretations of religion are also charged with greatly weakening (if not obliterating) distinctions between religions, between Islam and other religions, in particular. In his critique of fundamentalism 'Adel Dhaher expresses 'the doctrinal essence of Islam' briefly as 'believing in the unity of God, the perfection of morals, the establishment of justice and equality between people' (Dhaher 1993: 331). If this is what Islam reduces to, as Dhaher invites the reader to believe, doesn't this obliterate the distinction between Judaism, Christianity and Islam? For all these faiths have the same or a very similar doctrinal essence.

Finally, some critics question the very philosophical motives that lie behind liberalism in religion, something that must apply to liberal Islamism as well. This type of criticism can be found in Harris, who says that:

The only reason anyone is 'moderate' in matters of faith these days is that he has assimilated some of the fruits of the last two thousand years of human thought. The doors leading out of scriptural literalism do not open from the inside. The moderation we see among 
non-fundamentalists is not some sign that faith itself has evolved; it is, rather, the product of many hammer blows of modernism that have exposed certain tenet of faith to doubt.

(Harris 2004: 19)

Above and beyond these particular criticisms one may think that liberal Islamism does not in general represent an Islamic political modernity, but is an outright endorsement of a Western liberal conception of politics. One can see how much liberal Islamism seems to favor liberalism over Islam by looking at the demands that liberalism makes on religion, demands to which liberal Islamism accedes, but which are not reciprocal.

Here we need to recall Habermas' imperative for religious citizens to 'convincingly connect the egalitarian individualism and universalism of modern law and morality with the premises of their comprehensive doctrines' (Habermas 2006: 14), as well as Rawls' ideal of public reason which requires citizens to argue only in ways that other citizens as free and equal can be expected to accept (Rawls 1993: 1). In response to such demands, liberal Islamism calls for the privatization of Islam, and the differentiation between the political and the religious in ways that can neither be read off the main Islamic religious texts, nor have been practiced before. The extent of the 'surrender' that liberalized religion makes on this score has been persuasively expressed by Wolterstorff. He speaks for many religious citizens when he criticizes Rawls for thinking that:

... though religious people may not be in the habit of dividing their lives into a religious component and a non-religious component, and though some might not be happy doing so, nonetheless, their doing so would in no case be in violation of their religion. But [Rawls] is wrong about this. It is when we bring into the picture people for whom it is a matter of religious conviction that they ought to strive for a religiously integrated existence then especially, though not only then, does the unfairness of the liberal position to religion come to light.

(Wolterstorff 1997: 116)

Having said all of this against liberal Islamism, let us see what can be said in its defense. First, consider the charge of taking great liberties with religious texts, to the extent of making them mean something that they do not really mean. To say that liberal Islamists take liberties with texts presupposes the existence of an original and true meaning that is better, more accurately understood by fundamentalists and other non-liberals. The objection assumes that Islamists cannot speak the language of public reason, that is revelation is not mirrored by reason, that there is no way to Islamically justify a differentiation between faith and politics. Or, to sum it all up, the objector assumes that one cannot lead a religiously integrated existence without being opposed to modernity.

The disagreement between liberals and fundamentalists can without undue simplification be reduced to disagreement over answers to these basic questions: what does it take for one to be a Muslim? What is it for a society to abide by Islamic teachings? Different answers to these questions can yield different definitions of 'true' meaning and, consequently, different answers to the question about 'taking liberties' with texts.

Liberals (modernists) and fundamentalists approach these questions differently. Emphasis on revelation vs. emphasis on reason, adherence to the letter of the scripture vs. adhering to its spirit, reading revelations in context vs. viewing revelation ahistorically - all these distinctions have been called upon to explain the different approaches used by Islamists to answer major social and political questions. To these we can add a fourth distinction which puts us on a track 
Raja Bahlul

to answer questions about the meaning of 'Muslim' and 'Islamic'. It is a distinction between essential and non-essential aspects of the faith.

In saying this, one can hardly escape the suspicion of entertaining an 'essentializing view of Islam', a charge that is usually directed against those who say that Islamic ideas and practices never really change or undergo development. This is not what we have in mind when we talk about essential and non-essential aspects of the faith. The distinction we have in mind is closer to the old philosophical distinction between 'essence' and 'accident', the same distinction we use when we say, for example, that man is 'essentially rational', but only accidentally white or black. ${ }^{7}$ It is a distinction between features that really matter for the continued existence and identity of something, as opposed to those with respect to which something can change without loss of existence or identity. Far from presupposing that Muslims and Muslim life cannot change, it is precisely because Muslims and Muslim life can change that it makes sense to speak of what is essential and what is not.

Now instead of viewing texts in terms of what is (in one good use of the word) fundamental and what is not, fundamentalists and non-liberals tend to view texts as a conglomerate of equally important items. For example, many of them will agree with liberals that the basic message of the Qur'an with respect to women is progressive and liberating. They will cite verses that emphasize equality in the sight of God, how Islam granted women rights that they did not have in pre-Islamic times, and many similar arguments to this effect. When it is pointed out that there are Qur'anic verses that seem to discriminate against women, liberal Islamists find a way to suspend judgments contained in such verses, because they do not view all texts as being equally fundamental. Not so for fundamentalists: to them each stone in the Qur'anic edifice is a cornerstone, so that its removal threatens the whole edifice with collapse. This is why they will fight battles over such matters as the prohibition of foods and drinks, or modest dress. This represents a reduction of Islam to equally important elements, equating the general with the particular, the absolute with the conditional, the context-free with the context-dependent.

Of course, viewing matters in terms of what is essential and what is not does involve value judgments. At some point or other one must face the question of what is more important: the essential message of justice, goodness and mercy that Islam embodies, or the particular laws revealed and applied at particular times, and in particular situations that no longer obtain? Are they equally important from an Islamic point of view? What does God really care for? Does He care more for our living up to the values of goodness and justice, or is He more concerned about the style of a woman's dress? Are these equally important in the divine scheme of things? Depending on one's answer to these questions, one can take a position over interpreting or reinterpreting texts, how literal one can be, even what it means for something to be truly 'the word of God'.

Of course, it cannot be denied that much of the earlier history of religion is a history of fanaticism, conservatism and opposition to reason and science, but the validity of the liberal understanding of religion, Islam included, is not impugned by this fact. Critics who object to liberal Islamism on the ground of taking liberties with texts seem to assume that earlier generations have an epistemologically privileged understanding of religion because they are temporally closer to the point of origin. As a corollary of this assumption it is then thought that if the earlier generations were inspired to be fanatical, or conservative, or misogynist, then this is what religion really implies, that any softened interpretation of religion must be a willful deviation, or an unwilling concession to modernity.

These assumptions may be justified on a purely naturalistic understanding of religion, where one says that religion is a human invention. One could then say: this is what the inventors meant, and we have no right to replace their meaning by ours, using their words. On a religious view of 
religion, however, God is not closer to the earlier generations than $\mathrm{He}$ is to ours, nor need $\mathrm{He}$ favor their interpretation over ours. Hence the fact that their understanding of religion led them to intolerance, the fact it was only under the hammer blows of modernity that people learned to moderate their views - none of this impugns the validity of a modern understanding of religion. Drawing conclusions about validity of a liberal interpretation on the basis of the illiberal history from which it evolved comes close to committing the genetic fallacy. To impugn the validity of a position on the basis of the morally inadmissible motives that may lie behind it is a more or less straightforward instance of yet another fallacy - argumentum ad hominem.

None of this proves that liberal Islamism is true. At most it shows that it is a credible view. More than this is rarely achieved in the realm of philosophical and moral discussions, but it may be possible to provide additional strength by dwelling on questions of viability and desirability, and this we can do by comparing the modernizing moves of liberal Islamists with similar moves that have been underway in other faiths. Comparisons of history and intellectual content may show that Islamic religious consciousness is (or can be) travelling down a well-trodden path, a path that has been taken by others before. They can also reveal lessons to be learned and arguments to be examined. This is bound to make the case for liberal Islamism stronger.

\section{Comparisons}

Liberal Islamists are not unique in their belief that religion is not opposed to democracy, human rights or life in the modern world in general. Turabi's statement to the effect that democracy is underpinned by the Muslim belief in equality of all worshippers before God, corresponds to Siedentop's claim that 'The assumption that society consists of individuals [ ... ] is a translation of the Christian premise of the equality of souls in the eye of God' (Siedentop 1989: 308), an idea that may be taken to justify the individualism implicit in much modern liberal thinking. Fradkin refers to the fundamental place of the notion of liberty in the Jewish faith, as exemplified in the celebration of the Exodus from Egypt. He also refers to the egalitarianism contained in the idea of a Covenant between God and the people, since this idea requires the consent of the governed (Fradkin 2005: 97-100).

Nor is the claim of providing a suitable framework for democracy unique to the three monotheistic faiths, Judaism, Christianity and Islam. Hinduism, which neither worships one unique God nor claims one prophet, can be presented as favoring democracy. Mehta speaks of 'the supple, open, plural quality of Hinduism' as doing just that, despite the fact that 'dominant interpretations of Hinduism have favored caste for long' (Mehta 2005: 59).

The puzzle is not how it is that religious traditions with deep roots in the undemocratic past of mankind still manage to contain democratic meanings. Rather, it is why it took so long for these meanings to be discovered and, more interestingly, why it is that in some societies, but not in others, these meanings have been integrated into political practice.

The latter question is a pressing one for Muslim societies, because in the case of the two sister monotheistic faiths as well as distant Hinduism, it can be argued that religion has managed to strike a fairly stable, even if not completely satisfactory compromise with democratic politics. Religious parties exist and there are parties with religious allegiances and/or history. They participate in elections, share power, work by peaceful means for advancing their vision of the good society, and they seem to have come to terms with the existing pluralism in society, with all the tolerance and forbearing that this entails.

Some of the democracy-compliant religions (if one is permitted to use such a term) have a long history of opposition to democratic politics. According to the example discussed in detail by Daniel Philpott, Catholic Christianity in the past opposed not only democracy but the very 
Raja Bahlul

idea of the sovereign territorial state. In 1832 Pope Gregory XVI condemned the idea of freedom of conscience as 'absurd and erroneous opinion'. The Catholic Church continued to uphold the doctrine that temporal authorities ought to promote Church prerogatives well into the 20th century. Not until the 1930s did Church intellectuals begin to offer principled argument for the freedom of religion, and to provide foundations for constitutional democracy. By 1963 the Catholic Church had endorsed human rights, and after the end of the Cold War Pope John Paul II defended democracy as 'the form of government most conducive to justice and the mission of the Church' (Philpott 2005: 104).

The Christian democratic parties that have been active in European political life since World War II should provide an interesting subject of study to Islamists who want to see different models of the relation between religion and politics. When the notion of democracy started to circulate among Catholic intellectuals and Church members, this was accompanied by the realization of the political advantages of democracy: it offered the concept of a totality of political subjects with a large Catholic component that could be mobilized into a political power (Pombeni 2000: 295).

In the case of contemporary Islamist political movement, there can be hardly any doubt that part of their attraction to democracy and electoral politics is to be explained by reference to the realization that a politically free population with an overwhelmingly Muslim majority offers unprecedented political opportunities. This has been amply proved by the many political successes that Islamist movements have achieved in different parts of the Arab/Muslim world.

There is a major ideological difference between Christian democracy and popular mainstream Islamist political movements that really matter. With the passage of time, Christian democratic movements seem to have learned to express themselves in modern political idiom, drawing on the large repertoire of ideas and theories that have evolved in the West since the time when Christianity and Greco-Roman culture began to interact with each other. Thus when Christians express their political philosophy by emphasizing the values of community, respect for human life and personhood, opposition to materialism and economic disparities (with affinities to socialist critiques of liberal capitalism), they see themselves as at once standing on Christian ground, as well as speaking a language that other people, including the non-religious citizens, can understand. Christian democracy could not have attained a position of non-sectarian appeal without opting for what one writer calls a 'sort of minimal and secularized Christianity' (Pombeni 2000: 299). 'Minimal' is to be understood in terms of emphasis on matters of essence, and not on theological doctrine and fine distinctions. 'Secularization' can be taken to mean willingness to justify and argue using secular reasons that can be religiously grounded.

The two steps of 'minimalization' and 'secularization' have been taken by the liberal Islamists, who tend to view Islam (minimally) as an ethical-social message, and who are willing to use secular reasoning, believing that the use of 'reason' is sanctioned by revelation. The same cannot be said for popular mainstream Islamist movements. This can be seen in their demand for the constitutional privileging of Islam, the Islamization of laws in ways that hark back to distant times, and only serve to bring out Islamic particularism (e.g. Islamic penalties, laws of personal status).

Will the liberal message of liberal Islamism ever become politically popular? It is true that most Islamic successes in electoral politics have been achieved by less-than-liberal parties, but we may in fact be witnessing the first stages of the popularization of the political message of liberal Islam. Examples are provided by the Moroccan Party for Justice and Development, and the Wasat Party in Egypt (an off-shoot of the Muslim Brotherhood), which presents itself as 'a civil party with an Islamic reference point'. The more convincing example comes from Turkey, where Islamic political movements evolved under a regime of secularism for a relatively 
long time. Parties with a religious orientation in Turkey accept the secular regime with its republican modernizing project and democratic political system. Comparing his Islamic party to Christian democracy, Erdogan has been quoted as saying that 'A political party cannot have a religion, only individuals can. Religion is so supreme that it cannot be politically be exploited or taken advantage of (Altunisik 2005: 50).

More than political success will be needed to make the case for liberal Islamism. A genuine, deep and thorough-going engagement with modernity and modern ideas has to take place. This cannot be simply accomplished by singing the songs of political liberalism. Liberal Islamism must learn to criticize modernity, and it must dare to differ. ${ }^{9}$ Here it is possible to benefit from the example of the Christian critique of modernity.

Criticism of modernity from a Christian point of view has been going on for a long time. Muslims are late-comers to this enterprise, and they cannot claim to have experienced the full impact of modernity first-hand as its originators did. Still, they can learn many lessons from the Christian encounter with modernity. Probably the most important lesson to be learned is that the outcome of criticizing modernity cannot be a call for a historical reversal, a reversion to premodern modes of thought. The contemporary philosopher Charles Taylor, in calling for a 'Catholic modernity', still acknowledges the achievement of modern culture:

... modern culture, in breaking with the structures and beliefs of Christendom, also carried certain facets of Christian life further than they ever were taken or could have been taken within Christendom [ ... ] For instance, modern liberal political culture is characterized by an affirmation of universal human rights - to life, freedom, citizenship, self-realization which are seen as radically unconditional; that is, they are not dependent on such things as gender, cultural belonging, civilizational development, or religious allegiance, which always limited them in the past.

(Taylor 1999: 14)

There are many things that Taylor finds at fault in modernity. Among these is something that he refers to as exclusive humanism, a humanism that is 'based exclusively on a notion of human flourishing'. It is a humanism that believes 'that human life is better off without transcendental vision altogether' (Taylor 1999: 16). This is something that liberal Islamists can understand, for they cannot attribute an Islamic character to their endorsement of the values of human freedom, dignity, justice and goodness by confining themselves to reasoning in exclusively secular terms. They can argue, as Taylor does, that exclusive humanism, with its purely secular ideology, is not enough to ground morality in a fundamental way. For such humanism can be, and in fact has been, implicated in much violence, destruction and cruelty. Europeans can offer communism and Nazism as examples of secular ideologies that cut loose from religion only to produce horrid examples of human suffering. Liberal Islamism can point to similar, if less dramatic, examples in many parts of the Arab/Muslim world where secular ideologies prevailed for a time.

To find their own voice liberal Islamists must fight not only against exclusive humanism, but also against those who seek to answer exclusive humanism by turning to what may be termed exclusive theism. Exclusive theism is the belief, in effect, that only God exists, that human life is just a series of marginal notes on the existence of God. A belief like this can easily get man to turn his back on this world. The result will then be an ascetic, other-worldly ideal that represents a denial of life.

This is the box into which Christianity was painted by secular modernity, according to Taylor. Consequently, when modernity came along with its 'affirmation of ordinary (i.e. thisworldly) life', this was taken as a rejection of Christianity (a 'denial of transcendence') (Taylor 1999: 25). Liberal Islamists should be encouraged by the fact that it is not possible to portray 
Raja Bahlul

Islam in this fashion. Islam's whole-hearted embrace of ordinary life was never in doubt, as attested by the well-known Tradition that says 'Work for this world as if you would live forever. Work for the world to come as if you would die tomorrow'. Islam has no difficulty turning its face towards the world. This means that it can go a longer way towards accepting secular humanism without fear of betraying its essential message.

This is all the more reason for opening to the world with all its secular ideas and doctrines, always with an aim of learning from the truth that they may contain, but never losing sight of the fact that they are not enough to live by. At one point Habermas says that religious utterances 'bear a semantic potential that unleashes an inspiring energy for all of society as soon as they release their profane truth content' (Habermas 2006: 17), and so he urges secular society to listen patiently to the religious voices in it. A similar injunction can be made on behalf of secular voices: believers in religion (liberal Islamist or other) should also listen to secular voices because they, too, 'bear a semantic potential that unleashes an inspiring energy for all of society as soon as they release their religious truth content'.

Liberal Islamism, more than any other 'Islamism' that exists today, is well positioned to offer a balanced critique of modernity while being itself modern. It is not an easy task, because the temptation to go 'modern' all the way is there all the time, as the temptation to turn one's back on modernity completely. It is also difficult because this task cannot be accomplished without profound appreciation of both religion and modernity. However, we have no reason to believe that this is impossible.

\section{Notes}

1 For a discussion of this process of modernization with special reference to the secularization that accompanied it see Azmeh 1992.

2 See Brown 2000: chapters 3 and 4, for a thoughtful discussion of politically relevant differences between Christianity and Islam.

3 See Ghalyun 1979 for a discussion of the 'growing pains of secularization' consequent upon the imposition of this process from outside.

4 Rawls' formulation can be summarized thus: 1 Each person is entitled to equal basic rights and liberties compatible with similar rights and liberties of others. 2 Social and economic inequalities (if any) are to attach to positions that are open to all, and they must be of the greatest benefit to the least advantaged members of society (Rawls 1993: 6).

5 The notion of 'divine sovereignty', inherited from Mawdudi (Mawdudi 1975: 20-23), comes up frequently in discussions of the limits that many Islamist thinkers impose on 'popular sovereignty'. The notion seems to boil down to 'rule of law' (as opposed to arbitrary 'rule of men') (Bahlul 2000), but the notion of 'rule of law' does not say much until one knows what sort of law is under discussion.

6 For a detailed discussion of the prospects of accommodating constitutionalism within an Islamic framework of ideas, see Bahlul 2007.

7 The distinction between essence and accident is mainly associated with Aristotelian philosophy. It is interesting to note that, according to Aristotle, the distinction between male and female does not make for a distinction in the species (Aristotle 1941: 1058b, 1-6). This can be used to argue that the distinction between male and female is 'accidental', something which is bound to be welcomed by liberal feminists.

8 The Party goes as far as admitting injustices in the treatment of Copts in Egypt, and will accept non-Muslim members (Brown et al. 2006: 4).

9 According to Brown, much effort has been invested in justifying Islam to modernity. 'The implicit values of modernity [ ... ] were implicitly taken as the standard against which Islam was to be measured' (Brown 2000: 149).

\section{References}

'Abd al-Raziq, A. (1998) 'Message, Not Government, Religion, Not State', in C. Kurzman (ed.), Liberal Islam: A Sourcebook, Oxford, Oxford University Press. 
Abou el-Fadl, K. (2004) Islam and the Challenge of Democracy, Princeton, Princeton University Press.

Altunisik, M.B. (2005) 'The Turkish Model and Democratization in the Middle East', Arab Studies Quarterly vol. 27, nos. 1 \& 2: 45-61.

An-Na'im, A.A. (1990) Toward an Islamic Reformation: Civil Liberties, Human Rights, and International Law, Syracuse, Syracuse University Press.

Aristotle (1941) The Basic Works of Aristotle, R. McKeon (ed.), New York, Random House.

Asad, T. (1993) 'The Limits of Religious Criticism in the Middle East: Notes on Islamic Public Argument', in Genealogies of Religion, Baltimore and London, John Hopkins University.

Audi, R. (1997) 'Liberal Democracy and the Place of Religion in Politics', in R. Audi and N. Wolterstorff (eds), Religion in the Public Square: the Place of Religious Convictions in Political Debate, Lanham, Maryland, Rowman \& Littlefield Publishers.

Ayubi, N. (1991) Political Islam: Religion and Politics in the Arab World, London, Routledge.

Azmeh, A. (1992) Al-'Ilmaniyya min Manzur Mukhtalif [Secularism from a Different Perspective], Beirut, Markaz Dirasat al-Wihdah al-'Arabiyya.

(1993) Islams and Modernities, London, Verso.

(1994) 'Populism Contra Democracy: Recent Democratist Discourse in the Arab world', in Ghassan Salame (ed.), Democracy without Democrats? The Renewal of Politics in the Muslim World, London, I.B. Tauris.

Bahlul, R. (2000) 'People vs. God: the Logic of "Divine Sovereignty” in Islamic Democratic Discourse', Muslim-Christian Relations vol. 11, no. 3: 287-97.

(2007) 'Is Constitutionalism Compatible with Islam?', in P. Costa and D. Zolo (eds), The Rule of Law: History, Theory and Criticism, Holland, Springer.

Binder, L. (1988) Islamic Liberalism: A Critique of Development Ideologies, Chicago, The University of Chicago Press.

Brown, J.N., Hamzawy, A. and Ottaway, M. (2006) Islamist Movements and the Democratic Process in the Arab World: Exploring the Gray Zones, Carnegie papers: Middle East Series no. 67, Carnegie Endowment for International Peace, available at www.carnegieendowment.org/files/CP67.Brown.FINAL.pdf (accessed 10 March 2010).

Brown, L.C. (2000) Religion and State: The Muslim Approach to Politics, New York, Columbia University Press.

Denoeux, G. (2002) 'The Forgotten Swamp: Navigating Political Islam', Middle East Policy vol. 9, no. 2: $56-81$.

Dhaher, 'A. (1993) Al-'Usus al-Falsafiyah lil-'Almaniyah [Philosophical Foundations of Secularism], Beirut Dar al-Saqi.

Fradkin, H. (2005) 'Judaism and Political Life', in L. Diamond, M. Plattner and P.J. Costopoulos (eds), World Religions and Democracy, Baltimore and London, John Hopkins University Press.

Gellner, E. (1992) Postmodernism, Reason and Religion, London and New York, Routledge.

-(1993) 'Marxism and Islam: Failure and Success', in A. Tamimi (ed.), Power-Sharing Islam?, London, Liberty for Muslim World Publications.

Ghalyun, B. (1979) Al-Mas'ala al-Ta'ifyya wa Mushkilat al-'Aqaliyyat [The Sectarian Issue and the Problem of Minorities], Beirut, Dar al-Tali'a.

Ghannouchi, Sheikh Rashid (1993) Al-Hurriyat al-'Ammah fi al-Dawlah al-Islaymiyyah [Civil Liberties in the Islamic State], Beirut, Center for Arab Unity Studies.

Habermas, J. (1996) Between Facts and Norms, Cambridge, The MIT Press.

-(2006) 'Religion in the Public Sphere', European Journal of Philosophy vol. 14, no. 1: 1-25.

Harris, S. (2004) The End of Faith: Religion, Terror and the Future of Reason, London, The Free Press.

Hourani, A. (1962) Arabic Thought in the Liberal Age, Cambridge, Cambridge University Press.

Jadaane, F. (1981) 'Usus al-Taqaddum 'inda Mufakkri al-Islam fi al-'Alam al-'Arabi al-Hadith [Foundations of Progress According to Islamic Thinkers in the Modern Arab World], Beirut, al-Mu'assasah al-Arabyya lil-Dirasat wal-Nashr.

Khatami, M. (1998) Mutala'at fi al-Din wa al-Islam wa al-'Asr [Readings in Religion, Islam, and the Present Age], Beirut, Dar al-Jadid.

Kurzman, C. (ed.) (1998) Liberal Islam: A Sourcebook, Oxford, Oxford University Press.

Lassman, P. and Speirs, R. (1994) Weber: Political Writings, Cambridge, Cambridge University Press.

Lowrie, L.A. (1993) Islam, Democracy, the State, and the West: A Round Table with Dr. Hasan Turabi, WISE Monograph Series, no. 1, Tampa, Florida, The World of Islam Studies Enterprise.

Madi, A.I. (2005) Interview, 20 December, Arab Reform Bulletin, Carnegie Foundation for International Peace, available at www.carnegieendowment.org/files/Madi.pdf (accessed 10 March 2010). 


\section{Raja Bahlul}

Mawdudi, A. (1975) Tadwin ad-dustur al-Islami [The Codification of the Islamic Constitution], n.p., Mu'assat al-Risalah.

Mehta, P.B. (2005) 'Hinduism and Self-Rule', in L. Diamond, M. Plattner and P.J. Costopoulos (eds), World Religions and Democracy, Baltimore and London, John Hopkins University Press.

Philpott, D. (2005) 'The Catholic Wave', in L. Diamond, M. Plattner and P.J. Costopoulos (eds), World Religions and Democracy, Baltimore and London, John Hopkins University Press.

Pombeni, P. (2000) 'The Ideology of Christian Democracy', Journal of Political Ideologies vol. 5, no.3: 289-300.

Qaradawi, Y. (1993) Min Hady al-Islam [Islamic Guidance], Mansourah, Dar al-Wafa' lil-Nashr.

Rahman, F. (1980) Major Themes of the Qur'an, Chicago, Bibliotheca Islamica.

-(1982) Islam and Modernity: Transformation of an Intellectual Tradition, Chicago, University of Chicago Press.

Rawls, J. (1993) Political Liberalism, New York, Columbia University Press.

Siedentop, L.A. (1989) 'Liberalism: The Christian Connection', Times Literary Supplement, 24-30 March: 308.

Soroush, A. (1998) 'The Evolution and Devolution of Religious Knowledge', in C. Kurzman (ed.), Liberal Islam: A Sourcebook, Oxford: Oxford University Press.

Stepan, Alfred (2005) 'Religion, Democracy, and the "Twin Tolerations", in L. Diamond, M. Plattner and P.J. Costopoulos (eds), World Religions and Democracy, Baltimore and London, John Hopkins University Press.

Stowasser, B.F. (1993) 'Women's Issues in Modern Islamic Thought', in J. Tucker (ed.), Arab Women: Old Boundaries, New Frontiers, Bloomington and Indianapolis, Indiana University Press.

Talbi, M. (1992) 'Iyal Allah: Afkar Jadida fi 'Alaqat al-Muslim bi-Nafsihi wa-Alakharin [God's Family: New Ideas on the Relation of the Muslim to Himself and Others], Tunis, Ceres Publishers.

Taylor, C. (1999) 'A Catholic Modernity?', in J. Heft (ed.), A Catholic Modernity? Cary, NC, Oxford University Press.

Turabi, H. (1987) Qadaya al-Huriyya wa al-Wihda wa al Demoqratiyya [Questions of Freedom, Unity, Consultation, and Democracy], n.p., al-Dar al-Su'udiyya lil-Nashr.

Wolterstorff, N. (1997) 'The Role of Religion in Decision and Discussion of Political Issues', in R. Audi and N. Wolterstorff, Religion in the Public Square: the Place of Religious Convictions in Political Debate, Lanham, Maryland, Rowman \& Littlefield Publishers.

Woodbury, R.D. and Shah, T.S. (2005) 'The Pioneering Protestants', in L. Diamond, M. Plattner and P.J. Costopoulos (eds), World Religions and Democracy, Baltimore and London, John Hopkins University Press. 